\title{
Forage Pellets Quality From Weed Legetan With Different Composition
}

\author{
Bambang Suwignyo ${ }^{1, *}$ Rifqi Danang Subagya ${ }^{2}$, Andriyani Astuti ${ }^{1}$, Nafiatul Umami ${ }^{1}$, \\ and Ali Agus ${ }^{1}$
}

\author{
${ }^{I}$ Lecturer and researcher, Faculty of Animal Science, Universitas Gadjah Mada \\ ${ }^{2}$ Undergraduate students at Faculty of Animal Science, Universitas Gadjah Mada \\ "Corresponding author.Email: bsuwignyo@ugm.ac.id
}

\begin{abstract}
The aimed of the research conducted to determine the effect of composition on the quality of forage pellet. This study used fresh Legetan (Synedrella nodiflora) for major material of forage pellets, while rice bran was additional feed ingredients. There was two (2) variation of forage pellet consisting of A ( $80 \%$ Legetan $+20 \%$ rice bran) and B (90\% Legetan $+10 \%$ rice bran). These materials were formulated based on dry matter (DM). The mixture of ingredient were conducted in the form asfed, and then pelletized and dried (under sunlight) at Integrated Technical Implementation Unit (UPT), Forage and Pasture Science Laboratory, Faculty of Animal Science, Universitas Gadjah Mada. Each treatment replicated three (3). The experimental design was completely randomized design (CRD). The variables observed were DM, crude fiber $(\mathrm{CF})$, crude protein $(\mathrm{CP})$ and pelet durability index (PDI). The data were analyzed statistically with the help of the SPSS version 22 computer program. The significant differences then continued with the least significant different (LSD) test. The compositions of pellets forage affected the PDI, but not $\mathrm{DM}, \mathrm{CP}$, and $\mathrm{CF}$.
\end{abstract}

Keywords: Durability index, feed technology, forage pellet, Legetan weed.

\section{INTRODUCTION}

Forage is main feed source of ruminants. Forage is also source energy for ruminant, since ruminants has the ability to digest fiber and then convert into vollatyl fatty acid (energy source like glucose in non ruminant). Ultimately it can be described that fiber can be converted become milk and/or meat [1].

Unfortunately, people facing problem gap supply of feed between two season in Indonesia (dry and wet sesaon). Normally there is no problem of feed supply during wet season, but lack of supply during dry season [2]. People is looking for solution to maintain feed suplly in both season by feed technology processing [3]. Another side, Indonesia has abundant potential type of forage sources that can be used as feed for ruminant diet, weeds Legetan (Synedrella nodiflora) is one of it [4][5].

Legetan is high nutrition forage with crude protein (CP) reaching $20 \%$ or higher, and crude fiber more than $20 \%$ [4]. Legetan not only can be stored in the form of hay, but also can be processed as forage pellet [6]. The advantages of pellet form are not voluminous/ compact, easily stored, relatively stable in quality, can be combined with other materials, and less wasting when it given to the cattle [4]. There still open large opportunity to do research related to forage pellets with Legetan based. Therefore, needs to be conducting research activities with scooping about weeds for feed [5].

\section{MATERIAL AND METHOD}

The experiment was conducted at the Forage and Pasture Science Laboratory, Faculty of Animal Science, Universitas Gadjah Mada (UGM). The equipments used in the implementation of the research consisted of the chopper forage, trays, pelletizer machine, and the pellet dryer pedestal tarp. Ingredients used in this study were rice bran, and Legetan that harvested from the pasture land of Forage Forage and Pasture Science Laboratory.

This research was used different compositions of forage pellets. Legetan as forage pellet provide t $20 \%$ 
dry matter (DM), 23\% CP and 30\% crude fiber (CF) [5], rice bran contains DM $89.2 \%$ DM, ash $13.8 \%, 8.6 \%$ CP, $10.8 \%$ ether extract (EE), CF $21.6 \%$, and $45.33 \%$ nitrogen free extract (NFE) [7]. There were two (2) compositions of forage pellets, namely:

$\mathrm{A}=90 \%$ Legetan and $10 \%$ rice bran

$\mathrm{B}=80 \%$ Legetan and $20 \%$ rice bran

These materials were calculated based on the dry matter. The mixture of ingredient conducted in asfed. After, a mixed ingredient was pelletized and dried it under sunlight. This research activity was based on a completely randomized design (CRD). The data was statistically analyzed with SPSS version 22 computer program. The observed variables were $\mathrm{DM}, \mathrm{CF}, \mathrm{CP}$ and pellet durability index (PDI).

\section{RESULT AND DISCUSSION}

The results of nutrien contents of forage pellets based on the calculation from composition are shown in Table 1. below:

Table 1. Nutrien contents of forage pellets (\% DM) based on the calculation from its composition per $100 \%$

\begin{tabular}{|l|l|l|}
\hline \multirow{2}{*}{ Feed ingredients } & \multicolumn{2}{|c|}{ Type of forage pellets } \\
\cline { 2 - 3 } & $\mathrm{A}$ & $\mathrm{B}$ \\
\hline Rice bran & 10 & 20 \\
\hline Synedrellla nodiflora & 90 & 80 \\
\hline Total & 100 & 100 \\
\hline $\mathrm{CP}$ & 19.49 & 18.28 \\
\hline $\mathrm{CF}$ & 22.86 & 22.71 \\
\hline EE & 6.37 & 6.85 \\
\hline
\end{tabular}

The nutritional quality of the two types of pellets was calculated based on the nutritional content of the raw materials. Both types of pellets were almost nutritionally equivalent in terms of $\mathrm{CP}, \mathrm{CF}$ and $\mathrm{EE}$. The decreased in the number of forage component from $90 \%$ to $80 \%$ had not shown a significant decreased in the levels of CP, CF and EE forage pellets. This occured because the water content of grass was higher than that of rice bran [2,7] so that with the water content of forage Legetan weed which reached about $77 \%$, causing a reduction in the proportion from $90 \%$ to $80 \%$ in Legetan forage pellets, it could still be covered by an increased in the proportion of rice bran nutrients from $10 \%$ to $20 \%$.

\subsection{Pellet Durability Index}

The results of nutrien contents of forage pellets based on the analisis in the laboratorium are shown in Table 2. below:

Pellet durability index is one of the standart for physical pellet quality. The higher the PDI obtained the better the pellet quality. It means that the strength of a material made in pellet form will be guaranteed quality in terms of hardness and durability and save the feed, especially in terms of transportation and pellet packaging [8]. Factors that affect the durability value of pellets include the characteristics of the raw materials (protein, fat, fiber, and starch), density, texture, water and the stability of the characteristics of the material [9].

Table 2. Legetan forage pellet nutrient content

\begin{tabular}{|l|l|l|}
\hline \multirow{2}{*}{$\begin{array}{l}\text { Variables } \\
\text { measured }\end{array}$} & \multicolumn{2}{|c|}{ Type of forage pellets } \\
\cline { 2 - 3 } & A & B \\
\hline PDI & $97.20^{\mathrm{a}}$ & $95.90^{\mathrm{b}}$ \\
\hline $\mathrm{DM}$ & 50.49 & 50.65 \\
\hline $\mathrm{CP}$ & 12.38 & 12.81 \\
\hline CF & 19.79 & 20.43 \\
\hline $\begin{array}{l}\text { ab Different superscripts in the same column show significant } \\
\text { differences }(\mathrm{P}<0.05)\end{array}$
\end{tabular}

The results of the analysis of variance in the PDI value of forage pellets (Table 2) showed a significant difference $(\mathrm{P}<0.05)$. This was inseparable from the high protein content of the mixed legumes and concentrates. The minimum PDI specification standard is $80 \%$ [10]. The results obtained from the test show that Legetan's PDI was good, because it was above the minimum limit of the PDI standard. Pellets that have high durability will be more resistant to impact and friction, besides that pellets are also easier to handle and the possibility of de-mixing of the particles making up the pellets is smaller [11].

\subsection{Dry Matter}

Based on the results of the analysis of variance in the DM content of Legetan forage pellets (Table 2), there was no significant difference from the composition treatment to the DM content. This might be caused by a mutual subsidized factor between reducing Legetan forage $(90 \%$ to $80 \%$ ) and increasing rice bran (from $10 \%$ to $20 \%$ ). This is in accordance with the opinion of Chuzaemi and Hartutik [12] which states that feed ingredients are divided into water and DM. If the water content in the material is high then the dry matter contained in the material is low and vice versa.

\subsection{Crude Protein}

The content of $\mathrm{CP}$ in Legetan forage pellets according to Table 2. showed none of significant difference. The $\mathrm{CP}$ content of forage pellet was lower than CP content of Legetan in pellet formulation (Table 1). Suwignyo [4] stated that the CP content of Legetan was $20.11 \%$. These results showed a decrease in $\mathrm{CP}$ content by pelleting process. In addition, the pelleting process also affects the $\mathrm{CP}$ content due to protein denaturation by heating. On the other hand, starch 
gelatinization and protein denaturation are widely accepted as thermomechanical interactions that can improve pellet quality. Another factor can be caused vary quality of feed ingredient [13].

\subsection{Crude Fiber}

The results of the analysis of variance in the $\mathrm{CF}$ content of the forage Legetan pellets (Table 2) showed that there was no significant difference of $\mathrm{CF}$ content among treatments. This indicates that the composition of the pellets did not affect the CF content of the pellets. However, the $\mathrm{CF}$ content of forage pellets was lower than that the raw material (Table 1). Therefore, the livestock is easier to digest the Legetan by this pelleting process.

The content of CF is also a factor that affects the strength and durability of pellets in addition to starch, protein, lignin and fat [14]. Therefore, content of CF is an important factor in determining pellet quality. The main component of $\mathrm{CF}$ is in the form of carbohydrates consisting of cellulose compounds, some hemicelluloses, and lignin compounds that are difficult to digest [15]. An increase of CF content will reduce the digestibility of the feed.

\section{CONCLUSION}

The results showed that the composition of the raw materials for Legetan forage pellets had an effect on the pellet durability index but had no effect on dry matter, crude protein and crude fiber. Suggestion, continue the research with comparison of raw material between fresh and hay Legetan, and find out the effect on the quality of forage pellet.

\section{AUTHORS' CONTRIBUTIONS}

BS: designed and guided the study, and reviewed the manuscript. BS and RDS: collected data and pelletized Legetan weed. RDS and AA: managed the study and wrote the manuscript. NU and AA: reviewed the manuscript before submission. All authors read and approved the final manuscript

\section{ACKNOWLEDGMENTS}

The researchers wish to thank to Eprilia Aristia Rini and Dean Faculty of Animal Science for their support, discussion and assistance. Thank you to RTA programe of the year of 2021.

\section{REFERENCES}

[1] H. R. Kartadisastra, Penyediaan dan pengelolaan pakan ternak ruminansia, Kanisius. Yogyakarta, 1997.
[2] B. Suwignyo, B. Suhartanto, B. A. Suparja, W. Wahyudin, and G. Pawening, Effects of Different Season on Dominant Species and Chemical Composition of Tropical Agricultural Weeds, in International Seminar on Tropical Anima Production (ISTAP), 2017, pp. 57-61.

[3] B. Suwignyo, N. Umami, N. Suseno, W Wahyudin, and B. Suhartanto, Study For Dominance and Nutrition of Weeds As Feed in Various Crop Land in Yogyakarta, 17th AsianAustralasian Assoc. Anim. Prod. Soc. Anim. Sci. Congr., 2016.

[4] B. Suwignyo, A. Astuti, R. A. R. S. Putra, M. Danang, and E. Yulianto, Application of Appropriate Technology Forage Pellets for Emergency Response to Horse in Yogyakarta Andong Community Affected by Covid-19., 2020.

[5] B. Suwignyo, G. Pawening, M. H. Haris, N. Umami, N. Suseno, and B. Suhartanto, Effect of Organic and Inorganic Fertilizers on Yield and Quality of Synedrella nodiflora (Tropical Weed), Bul. Peternak., vol. 44, no. 4, 2020.

[6] I. Susilawati, Effect Of Binder On Physical And Chemical Quality Of Grass Pellet, J. Ilmu Ternak Univ. Padjadjaran, vol. 12, no. 1, 2012.

[7] H. Hartadi, A. D. Tillman, and S. Reksohadiprojo, Tabel komposisi pakan untuk Indonesia. Gadjah Mada University Press, 1990.

[8] Z. User, S. K. Syafura, and W. User, Penggunaan Pelet Ransum Lengkap dengan Sumber Hijauan Rumput Gajah (Pennisetum Purpurium) Untuk Pakan Ternak Ruminansia, Inov. Pembang. J. Kelitbangan, vol. 4, no. 03, pp. 254-267, 2016.

[9] I. Rahmana, D. A. Mucra, and D. Febrina, Kualitas fisik pelet ayam broiler periode akhir dengan penambahan feses ternak dan bahan perekat yang berbeda, J. Peternak., vol. 13, no. 1, pp. 33-40, 2016

[10] W. A. Dozier, Pellet quality for most economical poultry meat. J, Feed Int., vol. 52, no. 2, pp. 4042,2001 .

[11] F. Yusdema. AP, pengaruh jenis dan dosis leguminosa terhadap durabilitas dan densitas pelet konsentrat sapi perah, Students e-Journal, vol. 5, no. 4, 2016.

[12] S. Chuzaemi and Hartutik, 1990. Ilmu Makanan Ternak Khusus Ruminansia, NUFFIC. Univ. Brawijaya. Malang.

[13] D. E. Maier, J. Briggs, and B. A. Watkins, Effects of ingredients and processing conditions on the pelleting of feeds, Complet. Res. Summ. 
US Poult. Egg Assoc. Proj., no. 305, 1999.

[14] N. Kaliyan and R. V. Morey, Factors affecting strength and durability of densified biomass products, Biomass and bioenergy, vol. 33, no. 3, pp. 337-359, 2009.

[15] D. Tilman and D. Wedin, Plant traits and resource reduction for five grasses growing on a nitrogen gradient, Ecology, vol. 72, no. 2, pp. 685-700, 1991. 